\title{
Analisis Kinerja Dosen Mengajar Terhadap Kepuasan Mahasiswa Program Studi Manajemen Semester 2 Tahun Ajaran 2015-2016
}

\author{
Universitas Buana Perjuangan Karawang
}

Oleh

\section{CITRA SAVITRI}

Dosen Jurusan Manajemen

Fakultas Bisnis dan Ilmu Sosial

Universitas Buana Perjuangan Karawang

Citra.adien@gmail.com

\begin{abstract}
ABSTRAK
Human Resource is one of the best indicators in an effort to improve the quality for every company, no exception to the study program management in an effort to provide the best quality in the learning process is poss a good competence which is implemented through the faculty of pedagogy, professional ability, the personality ability and social ability. From the reality quality that's given, the authors formulate the problem as follows are: "how is the satisfaction of the teaching lecture performance against student satisfaction of management study program in the 2nd semester of the acadmic year 2015-2016 Buana Perjangan University Karawang

The purpose of the research is to measure the quality of teaching lecture performance against satisfaction management study program which has obtained every students for two semesters. The quality measurement uses the primary data through surveys, interviews and direct observation and distributing questionnaires to the correspondent of20people.
\end{abstract}

The result of research show the percentage of the the quality of teaching lecture performance in the study program management Buana Perjuangan University Karawang is very satisfaction where's the results obtained amounted to $66.66 \%$ and 
$33.33 \%$ every students are satisfaction with the teaching lecture performance in the study program management in the 2nd semester of the acadmic year 2015-2016. It means, the teaching lecture performance in management study program fulfill the expectations of student satisfaction. Nevertheless every lecturers should improve the learning methods in teaching and learning, other than as terms of tridharma of university but also for producing the highest human resources that have the highest competence and able to be competitive in the world of work later.

Keyword :Performance, Quality, Lecture, Satisfaction, Students.

\section{BAB I. PENDAHULUAN}

\subsection{Latar Belakang}

Sumber daya Manusia merupakan salah satu aset terpenting bagi negara untuk meningkatkan kemampuan dalam pertumbuhan dan pembangunan ekonominya. Semakin berkualitas Sumber daya Manusia yang dimiliki maka akan mempermudah proses pembangunan dan pertumbuhan suatu negara tersebut. Indonesia merupakan salah satu negara yang meiliki jumlah penduduk terbanyak ke empat di dunia. Ini berarti peluang bagi negara Indonesia untuk meningkatkan kualitas dari segala aspek sangatlah tinggi. Namun pada kenyataannya pertambahan jumlah penduduk masih menjadi masalah yang harus dipecahkan.

Pendidikan merupakan hal penting demi menghasilkan Sumber Daya Manusia yang berkompeten dan mampu bersaing dan berdaya guna baik seluruh orang dan organisasi. Semakin baik dan berkualitas pendidikan yang dienyam maka semakin besar peluangnya untuk menjadi seorang individu yang berkompetensi. Mahasiswa merupakan calon penerus bangsa yang diharapkan mampu untuk memberikan sumbangsihnya dalam pertumbuhan dan pembangunan suatu negaranya. Namun pada kenyataannya, banyak faktor yang menghalangi seorang untuk meraih kesuksesannya. Salah satunya adalah saat mahasiswa tidak memiliki motivasi dan 
minat pada mata kuliah tersebut atau tidak memiliki kepercayaan bahwa ia mampu menyelesaikan masalah. Selain pengaruh keluarga dan rumah tangga juga berpengaruh pada peningkatan kompetensi seorang mahasiswa.

\subsection{Identifikasi Masalah}

Dari permasalahan yang telah penulis kemukakan, maka dalam bahasan ini penulis akan merumuskan beberapa permasalahan tentang bagaimanakah tingkat kinerja dosen mengajar terhadap kepuasan mahasiswa program studi manajemen semseter 2 UBP Karawang tahun ajaran 2015-2016?

\section{BAB II . LANDASAN TEORI}

\subsection{Kualitas Pelayanan}

\subsubsection{Pengertian Kualitas}

Menurut Juran, Joseph M. (1994:64) kualitas berarti kesesuaian dengan penggunaan, suatu produk dapat dikatakan berkualitas jika produk tersebut memiliki kemampuan untuk memuaskan konsumen pemakainya (Quality in Costumer Satisfaction) maka kemampuan ini dimasukkan ke dalam 5 dimensi, yaitu:

1. Produk harus memenuhi harapan konsumen pemakainya.

2. Produk memiliki aturan penggunaan yang mudah

3. Produk harus dapat diandalkan (reliable) menurut spesifikasinya dan target produk tersebut.

4. Adanya pelayanan yang memadai untuk jasa perbaikan dan klaim kerusakan.

5. Adanya kemudahan dalam pemeliharaan dan ketahanan produk dalam jangka waktu yang cukup lama.

Pendapat lain disampaikan Schuler (1999:89) kualitas atau mutu berarti memberikan produk dan pelayanan yang konsisten mengikuti seluruh dimensi kualitas dalam satu 
usaha tunggal. Beraneka ragam definisi mengenai kualitas ini dikarenakan perbedaan perspektif atau pandangan yang digunakan.

Elliys L. Pambayun ( 1998 ), menyebutkan bahwa salah satu stategi dan pendekatan dalam meraih kesuksesan yang professional dan proporsional adalah dengan melakukan abdi layanan yaitu pelayanan paripurna yang merupakan syarat mutlak bagi organisasi yang bergerak dalam organisasi bisnis. Dari beberapa teori tersebut dapat disimpulkan bahwa kualitas berpusat kepada pelanggan dimana pelanggan mempunyai kebutuhan dan harapan tertentu atas kualitas pelayana yang diberikan dan kemampuan perusahaan dalam memberikan produk dan jasa secara baik dan benar. Pada penelitian ini penulis lebih cenderung menggunakan teori Parasuraman (1995).

\subsubsection{Kepuasan}

Kepuasan pelanggan adalah persepsi pelanggan bahwa harapannya telah terpenuhi atau terlampaui (Richard.F.Gerson, 2004:3). Kepuasan pelanggan bermakna perbandingan antara apa yang diharapkan konsumen dengan apa yang dirasakan konsumen ketika menggunakan produk tersebut. Bila konsumen merasakan performa produk sama atau melebihi ekspektasinya, berarti mereka puas. Sebaliknya jika performa produk kurang dari ekspektasinya, berarti mereka tidak puas.

Menurut Oliver, kepuasan adalah "tingkat perasaan seseorang setelah membandingkan kinerja atau hasil yang dirasakannya dengan harapannya". (J.Suprapto,2001:233). Menurut Richard Oliver (Husein Umar,2003:14) kepuasan pelanggan adalah "respon pemenuhan dari konsumen". Kepuasan adalah hasil penelitian dari konsumen bahwa pelayanan telah memberikan tingkat kenikmatan dimana tingkat pemenuhan ini bisa lebih atau kurang. Pengukuran kepuasan pelanggan, Kotler (2000: 38) menyebutkan sebagai "tools for tracking and measuring customer satisfaction“. Dapat didefinisikan ke dalam empat metode sebagai berikut yang salah satunya adalah survei kepuasan pelanggan. Metode ini dilakukan perusahaan dengan melakukan survei terhadap pelanggannya untuk mengukur 
kepuasannya terhadap produk jasa yang telah diterimanya. Cara ini dilakukan untuk mendapatkan umpan balik dari pelanggan, selanjutnya dapat dijadikan dasar pemikiran bagi perusahaan untuk menentukan program perusahaan dimasa mendatang.

\subsubsection{Faktor-faktor yang Mempengaruhi Kepuasan Pelanggan}

Kepuasan pelanggan harus disertai dengan pemantauan terhadap kebutuhan dan keinginan yang bisa dipengaruhi olehbeberapa faktor. Seperti yang diungkap oleh Cravens (1996:9) ada beberapa faktor kepuasan pelanggan yaitu:

\section{Sistem Pengiriman}

Memindahkan produk dari produsen ke pelanggan ataupemakai akhir dalam bisnis biasanya meliputi saluran distribusi dari para pemasok, pabrikan dan para perantara. Untuk dapat memuaskan pelanggan, jaringan ini harus berfungsi sebagai unit yang terpadu dan terkoordinir, di mana semua anggotanya mengerti dan menanggapi kebutuhan dan keinginan pelanggan.

2. Performa produk atau jasa

Performa dan keunggulan suatu produk atau jasa sangatlah penting dalam mempengaruhi kepuasan pelanggan, yang bias disebut sebagai hal utama dalam bersaing.

\section{Citra}

Citra dan merek perusahaan yang baik merupakan keunggulan bersaing yang mempengaruhi tingkat kepuasan pelanggan dari sudut positif. Terbentuknya citra merek (brand image) dan nilai merek (brand equity) adalah pada saat pelanggan memperoleh pengalaman yang menyenangkan dengan produk.

4. Hubungan harga-nilai

Pelanggan mengiginkan nilai yang ditawarkan merek sesuai dengan harga yang diberikan, oleh karenanya terdapat hubungan yang menguntungkan antara harga dan nilai. Merek dipromosikan oleh perusahaan sebagai suatu nilai yang unik sesuai harganya. Di lain pihak, manajemen memutuskan untuk bersaing atas dasar 
harga rendah di antara merek-merek di mana para pembeli sudah menetapkan nilai yang seimbang.

5. Kinerja atau Prestasi karyawan

Kinerja produk dan sistem pengiriman tergantung pada bagaimana semua bagian organisasi bekerjasama dalam proses pemenuhan kepuasan pelanggan. Setiap orang dalam organisasi mempengaruhi pelanggan, baik hal-hal yang menyenangkan atau pun yang tidak menyenangkan.

6. Persaingan

Kelemahan dan kekuatan para pesaing juga mempengaruhi kepuasan pelanggan dan merupakan peluang untuk memperoleh keunggulan bersaing. Pesaing yang spesifik menimbulkan dampak baik atau buruk dalam rangka memenuhi keinginan segmentasi pasar. Mengetahui kesenjangan (gap) antara keinginan pembeli dengan tawaran yang diberikan para pesaing merupakan peluang untuk meningkatkan kepuasan pelanggan.

\subsubsection{Kerangka Pikir}

Berdasarkan latar belakang masalah dan mengacu pada teoritis yang telah penulis kemukakan disimpulkan bahwa kinerja yang baik dan berkualitas dari dari seorang dosen akan melahirkan menghasilkan seorang mahasiswa yang berkompetensi. Peningkatan kompetensi akan terjadi jika seorang dosen mampu memberikan kualitas mengajar yang baik pula. Berdasarkan pernyataan yang dikemukakan di atas maka dalam hal ini penulis menggambarkan kegiatan tersebut ke dalam diagram berikut ini:

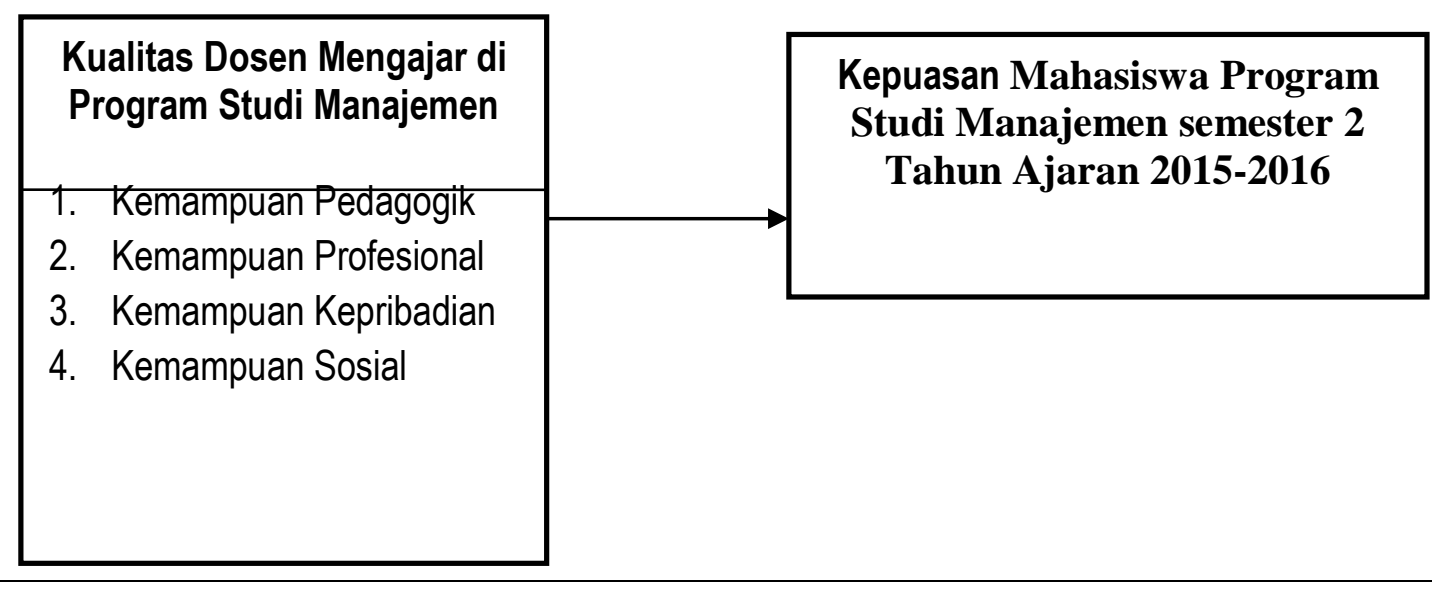




\section{Gambar 1. Diagram Kerangka Pikir}

\section{BAB III.METODE PENELITIAN}

\subsection{Metode Penelitian}

Metode penelitian yang penulis gunakan ialah metode deskriptif kualitatif, yaitu mendeksprisikan analisis kualitas kinerja dosen mengajar di program studi manajemen terhadap kepuasan mahasiswa program studi manajemen. Penilaian dilakukan dengan perhitungan analisis deskripsi untuk mengetahui kualitas kinerja terhadap kepuasan mahasiswa.

\subsection{Variabel Penelitian}

Penelitian ini penulis menggunakan satu variabel kualitas kinerja dosen mengajar terhadap kepuasan mahasiswa.

\subsubsection{Pengukuran Variabel}

Berdasarkan rencana pengukuran variabel penelitian ini, untuk mengetahui kualitas kinerja dosen mengajar terhadap kepuasan mahasiswa penulis menggunakan angket sebanyak 28 soal.

\begin{tabular}{|c|c|c|}
\hline No. & Pernyataan & Kompetensi \\
\hline 1. & $\begin{array}{l}\text { Kesiapan memberikan kuliah dan / atau praktek / } \\
\text { praktikum }\end{array}$ & Pedagogik \\
\hline 2. & Keteraturan dan ketertiban penyelenggaraan perkulihan & \\
\hline 3. & Kemampuan menghidupakan suasana kelas & \\
\hline 4. & $\begin{array}{l}\text { Kejelasan menyampaikan materi dan jawaban terhadap } \\
\text { pertanyaan }\end{array}$ & \\
\hline 5. & Pemanfaatan media dan teknologi pembelajaran & \\
\hline 6. & Keanekaragaman cara pengukuran hasil belajar & \\
\hline
\end{tabular}




\begin{tabular}{|c|c|c|}
\hline 7. & Pemberian umpan balik terhadap tugas & \\
\hline 8. & $\begin{array}{l}\text { Kesesuaian materi ujian dan / atau tugas dengan tujuan } \\
\text { mata kuliah }\end{array}$ & \\
\hline 9. & Kesesuaian nilai yang di berikan dengan hasil belajar & \\
\hline 10. & $\begin{array}{l}\text { Kemampuan menjelaskan pokok bahasan / topik secara } \\
\text { tepat }\end{array}$ & \multirow[t]{8}{*}{ Profesional } \\
\hline 11. & $\begin{array}{l}\text { Kemampuan memberikan contoh relevan dari konsep } \\
\text { yang di ajarkan }\end{array}$ & \\
\hline 12. & $\begin{array}{l}\text { Kemampuan menjelaskan keterkaitan bidang / topik yang } \\
\text { di ajarkan dengan bidang / topik lain }\end{array}$ & \\
\hline 13. & $\begin{array}{l}\text { Kemampuan menjelaskan keterkaitan bidang / topik yang } \\
\text { diajarkan dengan konteks kehidupan }\end{array}$ & \\
\hline 14. & $\begin{array}{l}\text { Penguasaan akan isu-isu mutahir dalam bidang yang di } \\
\text { ajarkan }\end{array}$ & \\
\hline 15. & $\begin{array}{l}\text { Penggunaan hasil-hasil penelitian untuk meningkatkan } \\
\text { kualitas perkuliahan }\end{array}$ & \\
\hline 16. & $\begin{array}{l}\text { Pelibatan mahasiswa dalam penelitian / kajian dan atau } \\
\text { pengembangan / rekayasa / desai yang di lakukan dosen }\end{array}$ & \\
\hline 17. & $\begin{array}{l}\text { Kemampuan menggunakan beragam teknologi } \\
\text { komunikasi }\end{array}$ & \\
\hline 18. & Kewibawaan sebagai pribadi dosen & \multirow[t]{6}{*}{ Kepribadian } \\
\hline 19. & Kearifan dalam mengambil keputusan & \\
\hline 20. & Menjadi contoh dalam bersikap dan prilaku & \\
\hline 21. & Santunnya kata dan tindakan & \\
\hline 22. & $\begin{array}{l}\text { Kemampuan mengendalikan diri dalam berbagai situasi } \\
\text { dan kondisi }\end{array}$ & \\
\hline 23. & Adil dalam memperlakukan mahasiswa & \\
\hline 24. & Kemampuan dalam menyampaikan pendapat & Sosial \\
\hline
\end{tabular}




\begin{tabular}{|l|l|}
25. & $\begin{array}{l}\text { Kemampuan menerima kritik, saran, dan pendapat orang } \\
\text { lain }\end{array}$ \\
\hline 26. & $\begin{array}{l}\text { Mengenal dengan baik mahasiswa yang mengikuti } \\
\text { kuliahnya }\end{array}$ \\
\hline 27. & $\begin{array}{l}\text { Mudah bergaul dikalangan sejawat, karyawan, dan } \\
\text { mahasiswa }\end{array}$ \\
\hline 28. & Toleransi terhadap keberagaman mahasiswa \\
\hline
\end{tabular}

\subsection{Populasi, Sampel dan Teknik Sampling}

\subsubsection{Populasi}

Populasi dalam penelitian ini adalah mahasiswa program studi manajemen angkatan tahun 2015 semester 2 tahun ajaran 2015-2016.

\subsubsection{Sampel}

Sampel dalam penelitian ini dengan mengambil sebagian mahasiswa program studi manajemen sebanyak 20 orang.

\subsubsection{Teknik Sampling}

Teknik sampling yang digunakan dalam penelitian ini adalah teknik random sampling dengan mengambil sebagian dari subjek penelitian.

\subsection{Teknik Pengumpulan Data}

\subsubsection{Teknik Pokok}

Teknik pokok yang digunakan dalam penelitian ini adalah memberi tes berupa Angket atau kuesioner merupakan teknik pengumpulan data yang dilakukan dengan cara memberi seperangkat pertanyaan atau pernyataan tertulis kepada responden untuk dijawabnya.

\subsubsection{Teknik Pelengkap}

Teknik pelengkap yang digunakan penulis untuk mengumpulkan data penelitian ini sebagai berikut:

\section{Observasi}

Teknik dokumentasi digunakan untuk melengkapi data-data yang berdasarkan data dokumentasi dan peninjauan ke lapangan. 


\section{Teknik Kepustakaan}

Teknik kepustakaan ini digunakan untuk mengkaji dan mencari teori-teori yang dapat mendukung penelitian ini dapat mencari sasaran dan tujuan yang diharapkan.

\subsection{Analisis Data}

Dalam penelitian ini analisis data dilakukan dengan cara:

1. Memberikan angket kepada mahasiswa program studi manajemen semester 2

2. Menganalisis dan mengumpulkan data penelitian

3. Mendeskripsikan data kualitas kinerja dosen mengajar terhadap kepuasan mahasiswa

\section{BAB IV. PEMBAHASAN}

Setelah diadakan penelitian dan analisis hasil angket kualitas kinerja dosen mengajar dengan kepuasan mahasiswa, maka diperolehlah hasil sebagai berikut:

\section{Angket Kualitas Kinerja Dosen Mengajar}

\begin{tabular}{|c|c|c|c|c|c|c|c|}
\hline \multirow{2}{*}{ No } & \multirow{2}{*}{ Smstr } & \multirow{2}{*}{ Mata Kuliah } & \multirow{2}{*}{ Dosen } & \multicolumn{4}{|c|}{ Kompetensi } \\
\hline & & & & 1 & 2 & 3 & 4 \\
\hline 1 & 2 & $\begin{array}{l}\text { Pendidikan } \\
\text { Agama Islam }\end{array}$ & $\begin{array}{l}\text { Aji Tuhagana,S.Ag, } \\
\text { SE,M.M., }\end{array}$ & 4,11 & 4,10 & 4,18 & 4,15 \\
\hline 2 & 2 & $\begin{array}{l}\text { Pendidikan } \\
\text { Kewarga } \\
\text { Negaraan }\end{array}$ & $\begin{array}{l}\text { Nadya Putri S, S.Pd, } \\
\text { M.Pd }\end{array}$ & 3,64 & 3,66 & 3,65 & 3,56 \\
\hline 3 & 2 & Bahasa Inggris 11 & $\begin{array}{l}\text { Flora } \\
\text { SE,M.M., }\end{array}$ & 4,20 & 4,00 & 4,17 & 4,24 \\
\hline 4 & 2 & $\begin{array}{l}\text { Pengantar } \\
\text { Manajemen }\end{array}$ & $\begin{array}{l}\text { Enjang Suherman, } \\
\text { SE,M.M., }\end{array}$ & 3,84 & 3,89 & 3,88 & 3,86 \\
\hline 5 & 2 & Pengantar & Wanta, SE,M.M., & 4,08 & 4,08 & 4,05 & 4,17 \\
\hline
\end{tabular}




\begin{tabular}{|c|c|c|c|c|c|c|c|}
\hline & & Manajemen & & & & & \\
\hline 6 & 2 & $\begin{array}{l}\text { Pengantar } \\
\text { Manajemen }\end{array}$ & Sihabudin,SE,M.M., & 3,96 & 3,94 & 3,93 & 4,04 \\
\hline 7 & 2 & $\begin{array}{l}\text { Pengantar } \\
\text { Manajemen }\end{array}$ & $\begin{array}{l}\text { Aji Tuhagana, S.Ag } \\
\text {,SE,M.M., }\end{array}$ & 4,04 & 3,98 & 3,95 & 4,13 \\
\hline 8 & 2 & $\begin{array}{l}\text { Pengantar } \\
\text { Ekonomi Mikro }\end{array}$ & $\begin{array}{ll}\text { Budi } & \text { Rismayadi, } \\
\text { SE,M.M., } & \end{array}$ & 4,16 & 4,09 & 4,04 & 4,09 \\
\hline 9 & 2 & $\begin{array}{l}\text { Pengantar } \\
\text { Ekonomi Mikro }\end{array}$ & Citra Savitri, SE,M.M., & 4,21 & 4,13 & 4,13 & 4,20 \\
\hline 10 & 2 & $\begin{array}{l}\text { Pengantar } \\
\text { Akuntansi ll }\end{array}$ & Wanta, SE, M.M., & 3,81 & 3,63 & 3,76 & 3,86 \\
\hline 11 & 2 & $\begin{array}{l}\text { Pengantar } \\
\text { Akuntansi ll }\end{array}$ & $\begin{array}{l}\text { Asep } \\
\text {,SE,M.M., }\end{array}$ & 3,79 & 3,91 & 3,97 & 3,80 \\
\hline 12 & 2 & $\begin{array}{l}\text { Praktek } \\
\text { Pengantar } \\
\text { Akuntansi ll }\end{array}$ & Wanta SE,M.M., & 3,70 & 3,72 & 3,78 & 3,81 \\
\hline 13 & 2 & $\begin{array}{l}\text { Praktek } \\
\text { Pengantar } \\
\text { Akuntansi ll }\end{array}$ & $\begin{array}{ll}\text { Asep } & \text { Jamaludin } \\
\text {,SE,M.M., } & \end{array}$ & 3,78 & 3,76 & 3,88 & 3,79 \\
\hline 14 & 2 & $\begin{array}{l}\text { Aplikasi } \\
\text { Komputer }\end{array}$ & Suroso ,SE,M.M., & 3,93 & 3,88 & 3,93 & 3,86 \\
\hline 15 & 2 & $\begin{array}{l}\text { Praktek Aplikasi } \\
\text { Komputer }\end{array}$ & Wanta, S,M.M., & 3,91 & 3,83 & 3,88 & 3,71 \\
\hline 16 & 2 & $\begin{array}{l}\text { Praktek Aplikasi } \\
\text { Komputer }\end{array}$ & Suroso,SE,M.M., & 3,91 & 3,91 & 3,89 & 3,99 \\
\hline 17 & 2 & $\begin{array}{l}\text { Praktek Aplikasi } \\
\text { Komputer }\end{array}$ & Flora Patricia,SE,M.M., & 4,14 & 4,05 & 4,06 & 4,12 \\
\hline 18 & 2 & $\begin{array}{l}\text { Statistik } \\
\text { Ekonomi } 1\end{array}$ & $\begin{array}{l}\text { Netti } \\
\text { Nurlenawaty,Ir,M.M., }\end{array}$ & 3,88 & 3,91 & 3,97 & 3,82 \\
\hline
\end{tabular}


Berdasarkan hasil evaluasi dosen dalam pelayanan pendidikan dan pengajaran menunjukkan kinerja semester genap TA.2015/2016 sudah baik, dimana 33,33\% dosen dengan nilai kinerja sangat baik; 66,6\% dan dosen dengan nilai kinerja sangat baik.

Hasil kuesioner dari mahasiswa menunjukkan bahwa rata-rata kinerja dosen Program Studi Manajemen Universitas Buana Perjuangan Karawang TA.2015/2016 sudah baik dengan rentang nilai yang sangat bervariasi. Nilai kinerja dosen tertinggi $85 \%$ dan nilai terendah 49\%. Dari 28 point pertanyaan dalam kuesioner tersebut pada umumnya hasilnya baik, penilaian yang rendah pada pertanyaan apakah kelas dimulai dan diakhiri tepat waktu (rata-rata 52\%), dan apakah dosen bersangkutan memberikan umpan balik kepada mahasiswa (rata-rata 48\%).

Penilaian kehadiran dosen mengajar dikelas $100 \%$ berada di atas Standar Minimum Pelayanan (SPM) Program Studi Manajemen Universitas Buana Perjuangan Karawang yang ditetapkan $86 \%$. Sedangkan untuk penilaian ketepatan penyerahan nilai oleh dosen kepada bagian akademik sangat bervariasi yaitu 60\% dosen menyerahkan nilai antara $1-7$ hari setelah ujian, $24,5 \%$ dosen menyerahkan nilai antara 8-14 hari dan 15,5\% dosen menyerahkan nilai setelah lebih dari 14 hari pelaksanaan ujian. Meskipun bobot penilaian ini rendah hanya 0,1\% dari total penilaian PBM, tetapi kehadiran dosen mengajar dikelas merupakan salah satu indikator disiplin dosen dalam menyelesaikan tugas.

\section{BAB V. KESIMPULAN DAN SARAN}

\subsection{Kesimpulan}

Hasil penelitian, pembahasan dan analisis data yang telah dilakukan, penulis menyimpulkan bahwa tingkat kepuasaan mahasiswa sangat puas dengan kinerja dosen yang baik dengan persentase $33,33 \%$, sementara pada tingkat sangat puas terhadap kinerja dosen mengajar sebesar $66,66 \%$. 


\subsection{Saran-saran}

Setelah diadakan penelitian, pembahasan, analisis data dan kesimpulan, selanjutnya penulis hendak memberikan saran-saran sebagai berikut:

1. Perencanaan yang dibuat perusahaan harus sesuai dengan visi, misi dan tujuan program studi manajemen yaitu Menjadi Program Studi yang Berkualitas, Mandiri dan Kompetitif dalam Bidang Ilmu Manajemen ditingkat ASEAN Tahun 2025.

2. Peningkatan pendidikan bagi setiap dosen mengajar agar menjadi seorang pendidik yang profesional

3. Melakukan pelatihan- pelatihan yang bertujuan untuk meningkatkan kemampuan dalam menulis yang akan diterapkan dalam perkuliahan

4. Evaluasi, pemantauan dan observasi setiap minggunya pada setiap kegiatan yang dilakukan oleh pihak pimpinan.

5. Peningkatan fasilitas dan layanan yang diberikan pihak Lembaga.

\section{DAFTAR PUSTAKA}

Alma. Buchari. 2007. Manajemen Pemasaran \& Pemasaran Jasa. Bandung: Alfabeta.

Amir, M. Taufiq. 2005. Dinamika Pemasaran: Jelajahi \& Rasakan. Jakarta: Raja Grafindo Persada.

Ariani, Dorothea Wahyu. 2003. Manajemen Kualitas Pendidikan Sisi Kualitatif. Jakarta: Ghalia Indonesia. 
Dessler, Gary. 2004. Manajemen Sumber Daya Manusia. Edisi kesembilan. Jakarta: Indeks Kelompok Gramedia.

Dharmmesta, S Bayu dan Handoko, Hani T. (2011). Managemen Pemasaran Analisis. Perilaku Konsumen. Yogyakarta: BPFE.

Engel, FJ. dkk, 1995, Perilaku konsumen Jilid 2, Alih Bahasa Budijanto, Binarupa Aksara, Jakarta:

Juran, Joseph, M. (1994). Merancang Mutu. Jakarta : Pustaka Binaman Pressindo.

Kottler,Philip, Kellen Lane. (2009).Manajemen Pemasaran, Erlangga

Lupiyoadi, Hamdani. 2001. Manajemen Pemasaran Jasa, Edisi Kedua. Jakarta : Penerbit Salemba Empat.

Kotler, Philip 1997. Manajemen Pemasaran, Analisis, Perencanaan, Implementasi Dan Kontrol . Penerbit CV. Salemba Empat. Jakarta.

Nasution. 2004. “Total Quality Management”. PT Gramedia Pustaka Utama: Jakarta.

Pamitra, Teddy. 2001. Perilaku Konsumen dan Komunikasi Pemasaran. Bandung: Remaja Rosda Karya.

Parasuraman. (2003) Pelayanan Pelanggan yang Sempurna. Jakarta : Gramedia

Salehuddin, 1999, Pengaruh kualitas jasa terhadap loyalitas pelanggan, Universitas Brawijaya Malang.

Supranto, J. 2001. Pengukuran Tingkat Kepuasan Pelanggan. Edisi Baru. PT. Rineka Cipta. Jakarta. 
Sari Aida, Evaluasi Kepuasan Nasabah atas Layanan Perbankan Berbasis Mobile

Schuler, Randall S. dan Jackson, Susan E, (1999). Manajemen Sumber Daya Manusia. Edisi Keenam. Jakarta Erlangga.

Subroto, Budiarto \& Dolly Sutajaya Nasution, 1994,Pengukuran tingkat kepuasan pelanggan, Institut Teknologi Bandung.( Tesis).

Sugiyono, 2000, Metode penelitian bisnis, Alfabeta, Bandung.

Sumarwan, Ujang. 2003. Perilaku Konsumen (Teori dan Penerapannya dalam Pemasaran). Bogor: Ghalia Indonesia.

Sunarto. 2003. Perilaku Konsumen. Yogyakarta: Ngeksigondo Utama.

Supranto J. 2001. Pengukuran Tingkat Kepuasan Pelanggan. Jakarta : Rineka Cipta

Yazid, 1999, Pemasaran jasa konsep dan implementasi, Ekonesia, Yogyakarta. 